\title{
ANALISIS PENGARUH INVESTASI, PDRB, JUMLAH \\ PENDUDUK, PENERIMAAN PEMBANGUNAN, DAN INFLASI \\ TERHADAP PENDAPATAN ASLI DAERAH (PAD) DI \\ KABUPATEN LOMBOK BARAT
}

\author{
Oleh: \\ Karlina Batik \\ Pemerintah Daerah Kalimantan Tengah \\ E-mail/No.Hp:batik_kar@yahoo.co.id
}

\begin{abstract}
Mark sense application autonomousing to expected region gets to give facility to region to even out its own housewifery, also give room opportunity for region to dig up and mendayagunakan is proprietary potency optimal ala. PAD as one of accepting region reflects to increase region independence. The greater PAD therefore points out that region progressively is able to dig up and utilizes source those are at its region. To the effect that wants to be reached in this research is menganalisis affecting investment, PDRB, population, Development acceptance, and inflation to PAD. Observed data in this research is time series's data with runtut time 1980 2007. Estimation model that is utilized is bifilar regression that ditranspormasikan goes to to form logarithm.
\end{abstract}

Key word: Financially Region, PAD, Investment, PDRB, Resident, Development acceptance, Inflation.

\begin{abstract}
Abstrak
Adanya pemberian otonomi kepada daerah diharapkan dapat memberikan keleluasaan kepada daerah untuk menyelenggarakan urusan rumah tangganya sendiri, juga memberikan peluang ruang bagi daerah untuk menggali dan mendayagunakan potensi yang dimiliki secara optimal. PAD sebagai salah satu penerimaan daerah mencerminkan tingkat kemandirian daerah. Semakin besar PAD maka menunjukkan bahwa daerah semakin mampu untuk menggali dan memanfaatkan sumber-sumber yang ada di daerahnya. Tujuan yang ingin dicapai dalam penelitian ini adalah menganalisis pengaruh investasi, PDRB, jumlah penduduk, Penerimaan Pembangunan, dan inflasi terhadap PAD. Data yang diamati dalam penelitian ini adalah data time series dengan runtut waktu 19802007. Model estimasi yang digunakan adalah regresi berganda yang ditranspormasikan ke bentuk logaritma.
\end{abstract}

Kata Kunci : Keuangan Daerah, PAD, Investasi, PDRB, Penduduk, Penerimaan Pembangunan, Inflasi.

\section{PENDAHULUAN}

Ciri utama suatu daerah yang daerah adalah ditandai oleh mampu melaksanakan otonomi kemampuan keuangan daerah. Halim 
(2001) menjelaskan bahwa cirri utama suatu daerah yang mampu melaksanakan otonomi, yaitu Kemampuan keuangan daerah artinya daerah harus memiliki kewenangan dan kemampuan untuk menggali sumber-sumber keuangan, mengelola dan menggunakan keuangan sendiri yang cukup memadai untuk menyelenggaraan pemerintahannya Ketergantungan kepada bantuan pusat harus seminimal mungkin, agar pendapatan asli daerah (PAD) dapat menjadi bagian sumber keuangan terbesar sehingga peranan pemerintah daerah menjadi lebih besar.

Dengan diberlakukannya Undang-Undang Nomor 33 Tahun 2004 tentang Perimbangan Keuangan antara Pemerintah Pusat dan Daerah merupakan paradigma yang sangat berarti bagi pengelolaan keuangan daerah, baik ditingkat Provinsi maupun Kabupaten/Kota.

Adanya pemberian otonomi kepada daerah diharapkan dapat memberikan keleluasaan kepada daerah dalam pembangunan daerah melalui usaha-usaha yang sejauh mungkin mampu meningkatkan partisipatif aktif masyarakat, karena pada dasarnya terkandung tiga misi utama sehubungan dengan pelaksanaan otonomi daerah dan desentralisasi (Mardiasmo, 2004) yaitu :

Menciptakan efesiensi dan efektivitas pengelolaan sumber daya daerah. Meningkatkan kuantitas pelayanan umum dan kesejahteraan masyarakat.Memberdayakan dan menciptakan ruang gerak bagi masyarakat untuk ikut serta dalam proses pembangunan. Oleh karena itu selain menggali sumber-sumber keuangan di daerah, pemerintah daerah harus sanggup pula untuk mengelola dan menggunakan secara efesien dan efektif keuangan daerahnya dalam rangka penyelenggaraan pemerintah daerahnya, agar ketergantungan kepada bantuan pemerintah pusat dapat ditekan semaksimal mungkin. Dengan berkurangnya ketergantungan kepada pemerintah pusat, maka PAD di daerah menjadi sumber keuangan utama. Kegiatan ini hendaknya didukung juga oleh kebijakan perimbangan keuangan pemerintah pusat dan daerah sebagai prasyarat dalam sistem pemerintahan Negara (Koswara,2000:50) 
Proses menuju kemandirian tersebut, terutama dari segi pembiayaan penyelenggaraan pemerintahan dan pembangunan selama ini masih dirasakan kurang. Hal ini tercermin dari peranan PAD terhadap APBD yang masih rendah, khususnya PAD Kabupaten/Kota.

Kabupaten Lombok Barat memiliki banyak sumber PAD, diantaranya berasal dari restribusi pelabuhan laut lembar dan kawasan wisata sengggi dan lain-lain. Walaupun sumber-sumber PAD cukup banyak namun kontribusi

Tabel 1. Kontribusi PAD Terhadap Penerimaan Daerah Tahun 2003-2006

\begin{tabular}{ccccc}
\hline \multirow{2}{*}{ No. } & Tahun & \multicolumn{2}{c}{ Jenis Penerimaan (Rp.000) } & \multirow{2}{*}{$\begin{array}{c}\text { Sumbangan } \\
(\%)\end{array}$} \\
\cline { 3 - 4 } & Anggaran & $\begin{array}{c}\text { Pendapatan Asli } \\
\text { Daerah }\end{array}$ & Dana Perimbangan & \\
\hline 1. & 2003 & 21.084 .349 .287 & 270.471 .121 .000 & 7.80 \\
\hline 2. & 2004 & 26.773 .520 .690 & 266.100 .793 .806 & 10.06 \\
\hline 3. & 2005 & 26.767 .867 .474 & 296.370 .030 .913 & 9.03 \\
\hline 4. & 2006 & 32.388 .707 .130 & 444.946 .322 .385 & 7.28 \\
\hline & Total & 107.014 .444 .581 & 1.277 .888 .268 .104 & 8.37 \\
\hline
\end{tabular}

Sumber : BPS Kabupaten Lombok Barat

Obyek sumber PAD adalah masyarakat setempat, jika pemerintah daerah dalam melaksanakan pemungutan PAD tidak memperhatikan kepentingan masyarakat daerahnya, maka pemerintah daerah akan mengalami kesulitan dalam upaya meningkatkan PAD.Salah satu aspek kepentingan masyarakat di daerah adalah
PAD terhadap penerimaan daerah masih kecil. Fenomena tersebut ditunjukkan oleh tabel 1. Pada table tersebut menunjukkan bahwa pendapatan daerah Kabupaten Lombok Barat masih kecil kontribusinya terhadap penerimaan daerah dan PAD Kabupaten masih sangat tergantung kepada sumber dana dari pusat, karena kemampuan dari sumber dana dari PAD hanya sekitar

8,37 persen. 
Pendapatan Asli Daerah (PAD) di Kabupaten Lombok Barat.

Secara teoritis, yang dimaksud dengan keuangan daerah adalah semua hak dan kewajiban yang dapat dinilai baik berupa uang maupun barang yang dapat dijadikan kekayaan daerah sepanjang belum memiliki atau dikuasai oleh Negara atau daerah yang lebih tinggi serta pihak-pihak lain sesuai ketentuan atau peraturan perundang-undangan yang berlaku (Mamesah,1997:16)

Manajemen keuangan daerah, penyusunan APBD bertumpu pada perencanaan tahunan. APBD sendiri terbagi atas tiga bagian yaitu anggaran penerimaan, anggaran pengeluaran dan anggaran pembangunan. Ketiganya dilakukan dengan pendekatanline-item dan incrementalism. Hal ini seringkali bertentangan dengan kebutuhan riil dan kepentingan masyarakat. Artinya pendekatan yang diterapkan lebih berorentasi pada anggaran dari pada kebutuhan.

Ketergantungan pemerintah daerah terhadap pemerintah pusat dalam hal keuangan masih relative tinggi, akibatnya akan mengganggu kelancaran pembangunan dan seringkali mematikan inisiatif dan prakarsa pemerintah di daerah sehingga program yang telah disusun berdasarkan kebutuhan daerah tidak dapat dilaksanakan. Konsep ekonomi daerah menjelaskan bahwa suatu daerah disebut sebagai daerah otonomi, jika daerah tersebut memiliki sumber-sumber keuangan. Hal tersebut diperlukan agar daerah dapat mengurus rumah tangganya sendiri dengan sebaik-baiknya. Salah satu sumber keuangan daerah adalah berasal dari Pendapatan Asli Daerah (PAD). PAD merupakan pendapatan yang berasal dari sumber-sumber keuangan daerah yang terdiri dari pajak daerah, restribusi daerah, bagian laba BUMN, penerimaan dinas-dinas dan penerimaan lain-lain (Kaho,1997:37).

PAD sebagai sumber utama pembiayaan kegiatan rutin dan pembangunan di daerah menuntut untuk selalu dan terus menerus dipacu pertumbuhannya. Jumlah dan kenaikan kontribusi PAD pemerintah kabupaten/kota akan dapat berperan dalam rencana peningkatan kemandirian pemerintah daerah untuk tidak selalu bergantung pada 
pemerintah pusat dan pemerintah provinsi.

\section{Kristiadi}

(1998:40-57)

menegaskan bahwa penerimaan daerah yang terpenting banyak tergantung pada tingkat pendapatan dan perekonomian setempat yang langsung dipengaruhi oleh tingkat perkembangan ekonomi nasional. Usaha peningkatan PAD yang tanpa memperhatikan efeknya terhadap kegiatan ekonomi dan potensi yang ada, akan menimbulkan gangguan terhadap kelancaran ekonomi dan perdagangan, bahkan akan menghambat sektor-sektor ekonomi tertentu.PAD dapat juga diartikan sebagai pendapatan yang digali dari sumber keuangan daerah itu sendiri. Hal ini berkaitan erat dengan penyelenggaraan tugas desentralisasi. Dengan banyaknya kebutuhan daerah dapat dibiayai oleh pendapatan asli daerahnya, maka semakin tinggi pula kualitas otonominya. Dengan demikian PAD yang mempunyai prospek yang cukup baik untuk setiap daerah otonom pada masa yang akan datang.

Djoyosubroto

mengemukakan bahwa kemampuan daerah dalam memobilisasi
Pendapatan Asli Daerahnya dapat diukur melalui

Peranan PAD dalam membiayai pengeluaran rutin pemerintah daerah yang bersangkutan;

Perbandingan antara PAD dengan PDRB non-migas masingmasing daerah. Ada berbagai faktor yang berpengaruh terhadap kemampuan keuangan daerah yaitu faktor eksternal yang meliputi,Investasi,PDRB， Jumlah Penduduk, Penerimaan Subsidi dari pemerintah pusat, Penerimaan pembangunan, Inflasi.

Pengaruh Investasi terhadap PAD Menurut Raharjo dan Manurung (2004:49) dalam teori ekonomi makro, investasi secara fisik adalah dalam bentuk barang dan modal (pabrik dan peralatan), bangunan dan persediaan barang (inventory) Dengan pembatasan tersebut, definisi investasi dapat lebih dipertajam sebagai pengeluaran-pengeluaran yang meningkatkan stok barang modal (capital stock). Yang dimaksud dengan stok barang modal (persediaan barang modal) adalah jumlah barang modal suatu 
perekonomian, pada satu saat tertentu. Untuk mempermudah perhitungan, umumnya stok barang modal dinilai dengan uang, yaitu jumlah barang modal dikalikan harga perolehan per unit barang modal. Dengan demikian barang modal merupakan konsep stock (stock concept), karena besarnya dihitung pada satu periode tertentu.

Menurut

Iswardono

(1999:232) pengikut Keynes menekankan bahwa tingkat bunga bukan merupakan veriabel kritis dalam menentukan permintaan investasi. Menurut mereka yang menjadi variable kritis adalah variable yang menentukan keuntungan yang diharapkan dan dikenal sebagai "Marginal Efficiency of Investment". Mereka berpendapat bahwa permintaan investasi adalah inelastic terhadap tingkat bunga. Hal ini berarti bahwa perubahan tingkat bunga membawa perubahan kecil pada permintaan investasi. Landasan pemikirannya adalah bahwa keuntungan yang diharapkan dari adanya investasi akan menurun dengan cepat jika tingkat bunga meningkat. Tetapi permintaan investasi akan berubah apabila faktor-faktor lain selain tingkat bunga mengalami perubahan.

Teori pertumbuhan ekonomi Horrod-Domar, secara jelas menyatakan bahwa tingkat pertumbuhan GDP (AY/Y) ditentukan secara bersama-sama oleh tabungan nasional, s, serta rasio modal-output nasional, k. Secara lebih spesifik pertumbuhan pendapatan nasional akan secara langsung atau secara "positif" berbanding lurus dengan rasio tabungan (yakni, semakin banyak bagian GDP yang ditabung dan diinvestasikan, maka akan lebih besar lagi pertumbuhan GDP yang dihasilkan) dan secara "negative" atau berbanding terbalik terhadap rasio modal-output dari suatu perekonomian (yakni, semakin besar rasio modal-output nasional atau $\mathrm{k}$, maka tingkat pertumbuhan GDP akan semakin rendah).

Oleh karena itu pengaruh investasi terhadap PAD sangat besar, oleh karenanya apabila investasi dapat masuk ke dalam suatu daerah, seperti Kabupaten Lombok Barat, dampaknya akan semakin luas terhadap pertumbuhan ekonomi, penyerapan tenaga kerja dan 
kemampuan masyarakat terhadap daya beli meningkat yang pada akhirnya akan berpengaruh pada kemampuan keuangan suatu daerah.

Pengaruh PDRB terhadap PAD, Pengertian PDRB adalah total nilai produk barang dan jasa yang diproduksi di wilayah (regional) tertentu dalam waktu tertentu (satu tahun) (Anonim,1997:1). PDRB dapat diukur melalui 3 macam pendekatan, yaitu : pendekatan produksi, pendekatan pendapatan, dan pendekatan pengeluaran. PDRB dapat diinterprestasikan menurut 3 pendekatan yaitu Menurut pendekatan produksi PDRB adalah jumlah nilai barang dan jasa yang dihasilkan oleh berbagai unit produksi di suatu wilayah dalam jangka waktu tertentu (biasanya satu tahun) (Anonim, 1997:2) Menurut pendekatan pengeluaran. PDRB adalah semua komponen permintaan akhir dari Pengeluaran konsumsi rumah tangga dan lembaga swasta yang tidak mencari untung.Konsumen pemerintah Pembentukan modal tetap domestic bruto.Perubahan stock eksport netto, dalam jangka waktu tertentu (biasanya satu tahun). Eksport netto merupakan eksport dikurangi import.

Menurut pendekatan pendapatan, PDRB merupakan jumlah barang dan jasa yang diterima oleh faktor produksi yang ikut serta dalam proses produksi di suatu wilayah dalam jangka waktu tertentu (biasanya satu tahun). Balas jasa faktor produksi yang dimaksud adalah upah dan gaji, sewa tanah, bunga modal dan keuntungan, semua sebelum dipotong pajak penghasilan dan pajak langsung lainnya. Dalam pengertian PDRB, kecuali faktor pendapatan termasuk pula komponen pendapatan persektor disebut sebagai nilai tambah bruto sektoral. PDRB merupakan jumlah dari nilai tambah bruto seluruh sektor (lapangan usaha). Hal ini sesuai dengan model pertumbuhan neoklasik dari Robert Solow yang mengemukakan bahwa secara kondisional, perekonomian berbagai negara akan bertemu (converge) pada tingkat pendapatan yang sama, dengan syarat bahwa negara-negara tersebut mempunyai tingkat tabungan, depresiasi, pertumbuhan angkatan kerja, dan pertumbuhan produktivitas yang sama.(Todaro:2006). 
Hubungan antara PAD dengan PDRB merupakan hubungan secara fungsional. Dengan meningkatnya PDRB maka akan menambah penerimaan pemerintah daerah untuk membiayai programprogram pembangunan. Selanjutnya akan mendorong peningkatan pelayanan pemerintah daerah kepada masyarakat yang diharapkan akan dapat meningkatkan produkvitasnya.

PDRB dibagi dengan jumlah penduduk pertengahan tahun yang tinggal di wilayah ini, maka akan diperoleh suatu PDRB perkapita, PDRB yang mengalami peningkatan cenderung akan mempengaruhi tenaga kerja yang akan diserap. Apabila upah tenaga kerja lebih tinggi maka hal ini secara tidak langsung akan menaikkan pendapatan perkapita masyarakat, sehingga masyrakat akan mampu membayar pajak daerah ataupun restribusi daerah, hal tersebut akan menambah sumber PAD (Mankiw,2002:19).

Pengaruh Jumlah Penduduk terhadap PADJumlah serta mutu penduduk suatu daerah merupakan unsur penentu yang paling penting bagi kemampuan memproduksi serta standart hidup suatu negara atau daerah. Namun demikian, yang paling utama mengapa masalah penduduk ini sangat menarik perhatian para pakar ekonomi adalah karena penduduk itu merupakan sumber tenaga kerja, human resource, di samping sumber faktor produksi skill (Rosyidi, 2002:87)

Apabila suatu daerah mempunyai jumlah penduduk yang sangat sedikit maka penduduk tidak akan mampu memanfaatkan sumbersumbernya dengan efisien sebagaimana yang mungkin dihasilkan jika jumlah penduduknya besar. Dalam keadaan seperti ini, usaha untuk mewujudkan produksi secara besar-besaran sangatlah tidak mungkin. Sebaliknya, apabila suatu daerah menderita over population, maka penduduk dapat memanfaatkan tanah ataupun modalnya seefesien mungkin, namun demikian karena penduduk terlalu banyak maka hasil yang diterima oleh setiap orangpun menjadi sangat kecil (Rosyidi,2002:92).

Oleh karena itu jumlah penduduk sangat berpengaruh dalam menentukan besarnya produksi suatu daerah. Dengan demikian jumlah 
penduduk sangat berpengaruh terhadap PAD di daerah tersebut.

Jumlah penduduk merupakan faktor yang sangat penting sebagai wajib pajak. Karena pajak adalah gejala sosial, artinya pajak hanya terdapat di dalam masyarakat. Jika tidak ada masyarakat berarti tidak ada pajak, sebab pajak dipungut untuk kepentingan masyarakat dalam pembangunan. Oleh karena itu, hubungan antara pajak dan masyarakat erat sekali. Pajak-pajak di dalam masyarakat dapat digunakan sebagai alat untuk mencapai tujuan ekonomi. Pajak juga dapat digunakan sebagai alat untuk meratakan pendapatan dengan menerapkan tarif yang progresif (Soemitro, 1997:41).

Pengaruh Penerimaan Pembangunan terhadap PAD, Seperti halnya pada penerimaan rutin, permasalahan yang ada pada penerimaan pembangunan sama. Dari segi bentuk dan strukturnya, komponen penerimaan pembangunan diseluruh pemerintah daerah diseragamkan menjadi 20 sektor. Selanjutnya dari segi alokasi dana, ukuran-ukuran kinerja yang baik seperti halnya pada pos penerimaan rutin, satu-satunya ukuran kinerja yang dipakai adalah aturan bahwa jumlah dana untuk penerimaan pembangunan yang tertera dalam anggaran daerah adalah jumlah dana maksimal yang dapat dibelanjakan untuk setiap pos penerimaan pembangunan. Dengan demikian, bila pada penerimaan rutin pemerintah daerah cenderung menghabiskan dana, maka pada penerimaan pembangunan hal yang sama juga terjadi. (Mardiasmo, 2004:174).

Pengaruh Inflasi terhadap PAD, Menurut Ackley (dalam Iswardono, 1999:213) bahwa yang dimaksud inflasi adalah suatu kenaikan harga secara terus menerus dari barang-barang dan jasa secara umum (bukan satu macam barang saja dan sesaat). Menurut definisi ini kenaikan harga yang sporadic bukan dikatakan sebagai inflasi.

$$
\text { Pengalaman di berbagai }
$$

Negara yang mengalami inflasi menunjukkan bahwa beberapa penyebab tetap inflasi yaitu terlalu banyaknya jumlah uang beredar, upah, krisis energy, paceklik, kekeringan dan deficit anggaran. Akan tetapi tidak satupun faktor 
tersebut mampu menjelaskan inflasi secara konsisten sepanjang waktu.

Kebanyakan model inflasi menekankan dampak kenaikan upah pada jumlah uang beredar sebagai penyebab utamanya, dan biasanya dikatakan bahwa ada dua jalur sebab antara jumlah uang beredar atau inflasi karena jumlah uang beredar yang berlebihan.

Tingginya inflasi seperti kondisi saat ini akan berakibat terhadap rendahnya daya beli masyarakat, dan sebaliknya, jika kondisi inflasi rendah akan berdampak pada pendapatan masyarakat pula. Dengan demikian akan berdampak terhadap peningkatan PAD pemerintah daerah Kabupaten Lombok Barat.

Jenis data yang digunakan adalah data time series, yaitu merupakan data tahunan seluruh variable yang diamati (Investasi, PDRB, dan Jumlah Penduduk, Penerimaan Pembangunan, dan Inflasi) sebanyak 84 data dari periode waktu tahun 1980 sampai dengan tahun 2007. Data tersebut diperoleh melalui BPS Kabupaten Lombok Barat.
Keuangan Daerah adalah sebagai suatu hak dan kewajiban yang dapat dinilai dengan uang maupun barang yang menjadi kakayaan daerah yang berhubungan dengan pelaksanaan hak dan kewajiban tersebut dalam batas wewenang daerah.

Pendapatan Asli daerah (PAD) adalah pendapatan asli daerah sendiri yang terdiri dari hasil pajak, restribusi daerah, pendapatan dari dinas-dinas, BUMN dan lain-lain, dihitung dalam ribuan rupiah per tahun.

Investasi adalah pengeluaranpengeluaran yang meningkatkan stok barang modal (capital stock) yang besarnya dihitung pada satu periode tertentu.

PDRB yang digunakan adalah PDRB menurut lapangan usaha atau dasar harga berlaku. Jumlah penduduk yang digunakan adalah jumlah penduduk akhir tahun Penerimaan Pembangunan yang dimaksudkan adalah sejumlah dana yang diterima oleh Kabupaten Lombok Barat dari Pemerintah Pusat dan Pemerintah Daerah Tingkat I. Inflasi adalah kenaikan harga secara terus menerus terutama terhadap 
barang-barang Sembilan bahan kebutuhan pokok yang terjadi selama tahun 1980-2007..

\section{METODE PENELITIAN}

Analisis yang digunakan dalam melakukan penelitian ini adalah regresi linier berganda dengan menggunakan metode OLS (Ordinary Least Square) yang digunakan untuk mengetahui hubungan antara Investasi, PDRB, Jumalh Penduduk, Penerimaan Pembangunan, dan Inflasi terhadap Pendapatan Asli Daerah (PAD) dinyatakan dalam persamaan matematis yang memiliki hubungan secara fungsional dengan formulasi sebagai berikut PAD $=\beta_{0}+\beta_{1} \mathrm{I}+$ $\beta_{2} \mathrm{PDRB}+\beta_{3} \mathrm{JP}+\beta_{4} \mathrm{PP}+\beta_{5} I F+\mathrm{e}_{\mathrm{t}}$. Keterangan $: P A D=$ Pendapatan Asli Daerah, $\mathrm{I}=$ Investasi, $\mathrm{PDRB}=$ Produk Domestik Rate Bruto. JP= Jumlah Penduduk, PP = Penerimaan Pembangunan, $\quad \mathrm{IF}=$ Inflasi, $\beta_{0}=$ Konstanta, $\beta_{1}, \beta_{2}, \beta_{3}, \beta_{4}, \beta_{5}=$ Koefisien Regresi, $\mathrm{e}_{\mathrm{t}}=$ error termDalam menilai ketepatan fungsi regresi untuk menaksir/memperkirakan nilai aktual dapat dilihat dari goodness of fit - nya, Secara statistik pengukuran tersebut dapat diperoleh dengan tahapan analisis sebagai berikut Uji F-Statistik,Uji t-statistik,Uji koefisien determinan $\left(\mathrm{R}^{2}\right), \quad, \mathrm{Uji}$ asumsi klasik

$$
\text { Uji F-statistik digunakan }
$$
untuk mengetahui seberapa besar pengaruh variabel bebas (independent) dalam persamaan regresi secara bersama-sama terhadap variabel terikat (dependent). Nilai F hitung diperoleh melalui rumus sebagai berikut :

$F=\frac{R^{2} /(k-1)}{\left(1-R^{2}\right) /(n-k)}$

Keterangan :

$\mathrm{R}^{2}=$ Nilai koefisien determinasi, $\mathrm{k}=$ Jumlah variabel dalam model regresi $\mathrm{n}=$ Jumlah observasi, Untuk pengujian dengan distribusi $\mathrm{f}$ menggunakan kaidah hipotesis sebagai berikut, Ho: $\beta_{1}=\beta_{2}=\beta_{3}=\beta_{4}$ $=\beta_{5}=0$, Makna dari kaidah tersebut adalah variabel I, PDRB, JP, PP, dan IF secara simultan tidak berpengaruh signifikan terhadap variabel PAD.

Hi: $\beta_{1} \neq \beta_{2} \neq \beta_{3} \neq \beta_{4} \neq \beta_{5} \neq 0$, Makna dari kaidah tersebut adalah variabel I, PDRB, JP, PP, dan IF secara simultan berpengaruh signifikan terhadap variabel PAD.Dengan menggunakan derajat kepercayaan sebesar $95 \%(\alpha=5 \%)$ 
dan derajat kebebasan (df), pembilang sebesar $(\mathrm{k})$ dan penyebut sebesar ( $\mathrm{n}-\mathrm{k}-1)$, maka interpretasi terhadap hasil perhitungan adalah sebagai beriku Jika F statistik < F tabel (F $\{\alpha, \mathrm{k}, \mathrm{n}-\mathrm{k}-1\}) \rightarrow \mathrm{Ho}$ diterima Jika F statistik > F tabel $(\mathrm{F}$ $\{\alpha, \mathrm{k}, \mathrm{n}-\mathrm{k}-1\}) \rightarrow$ Ho ditolak

Uji signifikansi parameter merupakan metode yang digunakan untuk mengetahui pengaruh secara parsial (individual) masing - masing variabel independent terhadap variabel dependent dalam persamaan regresi, dimana pengujiannya dilakukan dengan cara sebagai berikut (Yuliadi, 2009:68) :

$$
t-\text { hitung }=\frac{\beta_{i}}{S \beta_{i}}
$$

\section{Keterangan :}

$\mathrm{t}=$ Nilai $\mathrm{t}$ hitung $\beta_{\mathrm{i}}=$ Koesifien

regresi ke i $S \beta_{i}$

$$
\text { Hi: } \beta i \neq 0 ; i=1,2,3, \ldots, k,
$$

Maknanya, variabel I, PDRB, JP, PP, dan IF secara parsial berpengaruh signifikan terhadap variabel PAD. Dengan melakukan pengujian $t$ statistik dua arah, dengan derajat kepercayaan sebesar 95\% $(\alpha=5 \%)$, dan derajat kebebasan $(d f)$ sebesar (n - k - 1), maka interpretasi terhadap hasil perhitungan adalah sebagai berikut : Jika $-\mathrm{t}$ tabel $\leq \mathrm{t}$ statistik $\leq \mathrm{t}$ tabel $\rightarrow$ Ho diterima dan Jika $\mathrm{t}$ statistik $>\mathrm{t}$ tabel atau $-\mathrm{t}$ statistik $<-\mathrm{t}$ tabel $\rightarrow$ Ho ditolak

Uji $\mathrm{R}^{2}$ digunakan untuk menilai seberapa besar variasi (jumlah kuadrat simpangan suatu variabel dengan nilai rata - ratanya) dari variabel terikat dapat dijelaskan oleh variabel bebasnya (independent) dalam model regresi, sehingga dapat mengetahui kecocokan model regresi tersebut (goodness of fit). Koefisien determinan majemuk sendiri mempunyai dua sifat, yaitu: $\mathrm{R}^{2}$ merupakan besaran non negatif

Nilai $R^{2}$ berada diantara 0 sampai 1 , atau $0 \leq \mathrm{R}^{2} \leq 1$ dimana semakin dekat nilai $\mathrm{R}^{2}$ dengan 1 menunjukkan $\mathrm{R}^{2}$ yang semakin baik. Jika nilai $\mathrm{R}^{2}$ sama dengan 1 , maka

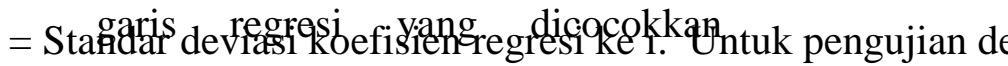
menjelaskan 100 persen variasi dalam variabel terikat. Sebaliknya, jika nilai $\mathrm{R}^{2}$ sama dengan 0 , maka garis regresi tidak menjelaskan sedikitpun variasi dalam variabel terikat.

Besarnya nilai $\mathrm{R}^{2}$ dapat diperoleh dengan menggunakan rumus berikut

$R^{2}=\frac{R S S}{T S S}=\frac{\sum e_{i}^{2}}{\sum y_{i}^{2}}=1$ 
Keterangan $\Sigma \mathrm{e}_{\mathrm{i}}^{2}=\Sigma$ kuadrat residual (Residual Sum of Squares, RSS) $\Sigma \mathrm{y}_{\mathrm{i}}^{2}=\Sigma$ kuadrat total (Total Sum of Squares, TSS). Dalam menganalisis sering terjadi beberapa masalah yang muncul pada saat analisis regresi untuk mengestimasi suatu model dengan sejumlah data variabel. Masalah yang terdapat didalam buku ekonometrika dasar termasuk dalam pengujian asumsi klasik yaitu ada atau tidaknya masalah multikolinieritas, heterokedastisitas, autokorelasi, dan normalitas (Gujarati. 2002:157).

Penyimpangan yang terjadi terhadap asumsi klasik tersebut akan menyebabkan uji f-statistik dan uji tstatistik yang dilakukan menjadi tidak valid dan secara statistik akan mengacaukan kesimpulan yang diperoleh. Pada dasarnya hasil dari estimasi persamaan regresi yang baik adalah hasil regresi yang memenuhi kriteria BLUE (Best Linear Unbiased Estimator), (Gujarati, 2002:44) maka dalam persamaan regresi dengan metode OLS, penelti merasa harus melakukan uji asumsi klasik untuk memperkuat hasil yang diperoleh dari analisis dengan macam - macam uji asumsi klaik sebagai berikut Diantara uji asumsi klasik yang hampir tidak bisa dihindarkan dalam suatu proses regresi dan korelasi data runtut waktu (time series) adalah permasalahan multikolinearitas. Multikolinearitas (sempurna) merupakan suatu keadaan dimana satu atau variabel independen dapat dinyatakan sebagai kombinasi linier dari variabel independen lainnya.

$$
\text { Peneliti menggunakan }
$$

metode Klein's rule of thumb yang dilakukan dengan menghitung koefisien korelasi antar variabel independen untuk menguji ada atau tidaknya multikolinearitas dalam model penelitian ini. Apabila nilai koefisien korelasi > 0,8, maka dapat dinyatakan bahwa model regresi tersebut memiliki masalah multikolinearitas dan jika nilai koefisien korelasi $<0,8$, maka dapat dinyatakan bahwa model regresi tidak memiliki masalah multikolinearitas.

$\begin{array}{lcr}\text { Tujuan } & \text { dari } & \text { Uji } \\ \text { heterokedastisitas } & \text { adalah } & \text { untuk } \\ \text { mendeteksi terjadinya nilai } & \text { varian } \\ \text { yang berbeda untuk setiap } & \text { varian } \\ \text { variabel - variabel } & \text { bebas } \\ \text { (Independent) di dalam } & \text { model }\end{array}$


regresi. Adanya masalah heterokedastisitas menyebabkan hasil taksiran regresi menjadi kurang atau lebih dari seharusnya. Sehingga penaksiran koefisien - koefisien regresi menjadi tidak signifikan.

Untuk mendeteksi ada atau tidaknya masalah heterokedastisitas model regresi didalam penelitian ini peneliti menggunakan uji White. Uji white merupakan uji yang menggunakan residual kuadrat sebagai variabel terikat (dependent), dan variabel bebasnya (independent) yang terdiri atas variabel bebas yang sudah ada, ditambah dengan kuadrat variabel bebas, ditambah perkalian variabel bebasnya. Dalam penelitian ini, pengujian Heteroskedastisitas dilakukan dengan uji hipotesis dengan Ho: Untuk data yang tidak bersifat Heterokedastisitas, dan Hi: Untuk data yang bersifat Heterokedastisitas dengan asumsi sebagai berikut :

Jika dari hasil regresi tersebut nilai Obs*R - squared $\left(n . R^{2}\right)<$ nilai $\chi^{2}$ tabel pada tingkat kesalahan $(\alpha)$ $5 \%$, atau nilai $\mathrm{P}<0.05$ maka $\mathrm{Ho}$ diterima, sehingga data tidak terdapat masalah heterokedastisitas. Sebaliknya, jika dari hasil regresi nilai $\mathrm{Obs}^{*} \mathrm{R}$ - squared $\left(n \cdot R^{2}\right)>$ nilai $\chi^{2}$ tabel, atau nilai $\mathrm{P}<0.05$ maka $\mathrm{Hi}$ diterima, sehingga data terdapat masalah heterokedastisitas.

Dalam model regresi linier klasik dapat diasumsikan bahwa unsur gangguan yang berhubungan dengan observasi tidak dipengaruhi oleh unsur gangguan yang berhubungan dengan observasi lain (disturbansi) yang dapat menyebabkan terjadinya autokorelasi. Adanya permasalahan autokorelasi akan menyebabkan hasil taksiran regresi menjadi tidak signifikan.

Autokorelasi merupakan korelasi antara anggota serangkaian observasi yang diurutkan menurut waktu (time series) atau ruang (cross section). Adapun penyebab Autokorelasi adalah kelambanan (inersia), Bias spesifikasi : kasus variabel yang tidak dimasukkan, Bias spesifikasi : bentuk fungsional yang tidak benar, fenomena Cobweb, keterlambatan waktu (lag) dan manipulasi data (Gujarati, 2002:157205). 
Tabel 2 : Uji Durbin - Watson

\begin{tabular}{|c|c|c|c|c|}
\hline $\begin{array}{c}\text { Tolak Ho = } \\
\text { ada } \\
\text { autokorelasi } \\
\text { positif }\end{array}$ & $\begin{array}{c}\text { Tidak dapat } \\
\text { diputuskan } \\
=\text { ada } \\
\text { autokorelasi } \\
\text { negatif }\end{array}$ & $\begin{array}{c}\text { Tidak } \\
\text { menolak Ho } \\
=\text { tidak ada } \\
\text { autokorelasi }\end{array}$ & $\begin{array}{l}\text { Tidak dapat } \\
\text { diputuskan } \\
=\text { ada } \\
\text { autokorelasi } \\
\text { negatif }\end{array}$ & $\begin{array}{c}\text { Tolak Ho = } \\
\text { ada } \\
\text { autokorelasi } \\
\text { negatif }\end{array}$ \\
\hline & & 2 & & \\
\hline
\end{tabular}

Untuk mendeteksi ada atau tidaknya autokorelasi di dalam model penelitian, peneliti menggunakan uji Durbin - Watson, dengan hipotesis Ho : data tidak ada autokorelasi dan $\mathrm{Hi}$ : data terdapat autokorelasi. Uji ini mendekeksi ada tidaknya masalah autokorelasi dengan cara mencocokan nilai Durbin - Watson statistik pada hasil estimasi model regresi sesuai dengan tabel uji diatas. (Gujarati, 2002: 216)

Uji Normalitas merupakan uji untuk mengetahui normal atau tidaknya faktor pengganggu $e_{t}$ (error terms). Sebagaimana telah diketahui bahwa faktor pengganggu diansumsikan memiliki distribusi normal sehingga uji t-Statistik dan fStatistik dapat dilakukan.

Metode yang digunakan dalam penelitian ini untuk mendeteksi masalah normalitas adalah dengan menggunakan Jarque - Bera test ( $J$ - B test). Langkah - langkah dalam melakukan uji tersebut adalah sebagai berikut:

Melakukan estimasi dengan menggunakan persamaan model yang diamati,

Menghitung nilai J - B Statistik dengan menggunakan rumus $I-B=n\left[\frac{S^{2}}{6}+\frac{(K-3)^{2}}{24}\right]$ dimana:

$\mathrm{S}=$ Nilai Skewness $\mathrm{K}=$ Nilai Kurtosis $\mathrm{N}=$ Jumlah data observasi 3.Kemudian bandingkan nilai $\mathrm{J}$ - B Statistik dengan nilai $\chi^{2}$ tabel dengan pedoman sebagai berikut: Jika nilai J - B statistik > nilai $\chi^{2}$ atau nilai $\mathrm{P}<$ 0.05 tabel berarti hipotesisnya menyatakan bahwa residual $\mathrm{u}_{\mathrm{t}}$ adalah berdistribusi nomal ditolak, sedangkan Jika nilai J - B statistik < nilai $\chi^{2}$ atau nilai $\mathrm{P}>0.05$ tabel berarti hipotesisnya menyatakan bahwa residual $u_{t}$ adalah berdistribusi nomal tidak ditolak. 
Sebelum

dilakukan

interpretasi atas hasil regresi, terlebih dahulu dilakukan pengujian penyimpangan terhadap asumsiasumsi klasik dari metode OLS (Ordinary Least Square), sehingga dapat diketahui apakah model yang dipakai tersebut relevan atau tidak. Pengujian yang dilakukan meliputi uji multikolinieritas, heterokedastisitas autokorelasi dan normalitas. Secara lengkap disajikan pada Lampiran 3.

Uji multikolinieritas digunakan untuk menguji apakah Tabel 3. Nilai Korelasi Parsial

\begin{tabular}{cccccc}
\hline & I & PDRB & JP & PP & IF \\
\hline I & & 0.292205 & -0.244546 & 0.162387 & 0.085385 \\
\hline PDRB & 0.292205 & & 0.066426 & 0.651192 & 0.037256 \\
\hline JP & -0.244546 & 0.066426 & & 0.212805 & -0.133731 \\
\hline PP & 0.162387 & 0.651192 & 0.212805 & & -0.136827 \\
\hline IF & 0.085385 & 0.037256 & -0.133731 & -0.136827 & \\
\hline
\end{tabular}

Sumber: Data Penelitian Diolah

Berdasarkan tabel 3, nilai korelasi dari kelima variabel bebas yaitu I, PDRB, JP, PP, dan IF menunjukkan nilai kurang dari 0.8 , sehingga dapat diambil kesimpulan bahwa model regresi tersebut bebas dari masalah multikolinieritas.

Uji heterokedastisitas bertujuan untuk mendeteksi terjadinya nilai varian yang berbeda dari setiap varian variabel bebas pada model regresi ditemukan adanya korelasi antar variabel bebas yaitu variabel I, PDRB, JP, PP,dan IF. Untuk mengetahui keberadaan multikolinieritas, maka dapat digunakan metode Klein's rule of thumb yang dilakukan dengan menghitung koefisien korelasi antar variabel bebas dengan tingkat signifikansi model regresi bebas dari masalah multikonieritas yakni $<0,8$. Dari hasil perhitungan dengan menggunakan software eviews 6.0 dalam pengujian multikonieritas, diperoleh hasil sebagai berikut:

\section{(n)}


Tabel 4: Pengujian Heterokedastisitas dengan Uji White

$\begin{array}{|ll|}\text { R-Squared } & =0.999 \\ \text { Obs } * \text { R-Squared } & =27.985 \\ \text { Prob } & =0.109 \\ \mathrm{~N} & =28\end{array}$

Sumber: Data Penelitian Diolah

Berdasarkan tabel 4, dapat diperoleh hasil Obs* $\mathrm{R}$-squared $(\mathrm{N}$ x R. Squared) $=28 \times 0.999=27.985$. dan nilai Sig (Prob) sebesar 0.109. karena nilai Prob > 0.05, maka dapat disimpulkan bahwa hasil regresi antara I, PDRB, JP, PP, dan IF terhadap PAD, tidak terdapat masalah heterokedastisitas.

Uji autokorelasi digunakan untuk mengetahui ada atau tidaknya masalah aotokorelasi dimana unsur gangguan yang berhubungan dengan observasi dipengaruhi oleh unsur disturbansi atau gangguan yang berhubungan dengan observasi lain. Untuk mengetahui adanya autokorekasi dalam suatu model regresi dilakukan dengan pengujian terhadap nilai uji Durbin Watson (DW) dengan ketentuan sebagai berikut (dari tabel Durbin Watson diperoleh nilai dL sebesar 1.571 dan dU sebesar 1.780, sehingga diperoleh 4-dU sebesar 2.220 dan 4-dL sebesar 2.429):

Tabel 5: Pegujian Autokorelasi Durbin Watson

\begin{tabular}{ll}
\hline \multicolumn{1}{c}{ Nilai Durbin Watson } & \multicolumn{1}{c}{ Kesimpulan } \\
\hline Kurang dari 1.571 & Ada autokorelasi \\
\hline 1.571 sampai dengan 1.780 & Tanpa Kesimpulan \\
\hline 1.780 sampai dengan 2.220 & Tidak ada autokorelasi \\
\hline 2.220 sampai dengn 2.429 & Tanpa Kesimpulan \\
\hline lebih dari 2.429 & Ada autokorelasi \\
\hline
\end{tabular}

Berdasarkan tabel 5, IF terhadap PAD, tidak terdapat diperoleh hasil regresi nilai DW-Stat sebesar 2.161 maka dapat di ambil kesimpulan bahwa nilai DW statistik terletak antara interval 1,780 sampai dengan 2,220. Sehingga dapat diambil kesimpulan bahwa model regresi antara I, PDRB, JP, PP, dan masalah autokorelasi.

Uji Normalitas merupakan uji untuk mengetahui normalitas (normal atau tidaknya) faktor pengganggu $e_{t}$ (error terms). Sebagaimana telah diketahui bahwa faktor pengganggu tersebut 
diansumsikan memiliki distribusi normal sehingga uji t-Stat dan F-Stat dapat dilakukan. Untuk dapat menguji normalitas model regresi, penelitian ini menggunakan metode
Jarque-Bera test $(J-B$ test $)$. Dari hasil perhitungan dengan menggunakan software eviews 6.0 diperoleh nilai Jarque-Bera statistik sebagai berikut:

Tabel 6: Pegujian Normalitas Jarque-Bera test (J-B test)

\begin{tabular}{lr}
\hline Skewness & 0.287 \\
\hline Kurtosis & 6.837 \\
\hline Jarque-Bera & 17.564 \\
\hline Probability & 0.001 \\
\hline
\end{tabular}

Dari tabel 6, nilai JarqueBera statistik model regresi menujukkan nilai 17.564 dengan Probability sebesar 0.0001. Karena nilai Prob masih lebih kecil dari 0.05 (tingkat kesalahan 5\%), maka asumsi normalitas belum terpenuhi. Dari hasil pengujian asumsi, tiga asumsi yaitu multikolinieritas, autokorelasi, dan heteroskedastisitas telah terpenuhi, akan tetapi asumsi normalitas tidak terpenuhi, sehingga perlu dilakukan tindakan perbaikan untuk mengatasi masalah normalitas. Gujarati (2002) menyatakan bahwa untuk mengatasi asumsi normalitas yang tidak terpenuhi, yaitu data ditransformasi. Salah satu transformasi yang tepat pada data yang memiliki skala yang berbeda adalah transformasi logaritma.
Sehingga perlu dilakukan pengujian ulang terhadap data transformasi.

Sebelum dilakukan interpretasi atas hasil regresi, terlebih dahulu dilakukan pengujian penyimpangan terhadap asumsiasumsi klasik dari metode OLS (Ordinary Least Square), sehingga dapat diketahui apakah model yang dipakai tersebut relevan atau tidak. Pengujian yang dilakukan meliputi uji multikolinieritas, heterokedastisitas autokorelasi dan normalitas. Secara lengkap disajikan pada Lampiran 5.

Uji multikolinieritas digunakan untuk menguji apakah pada model regresi ditemukan adanya korelasi antar variabel bebas yaitu variabel I, PDRB, JP, PP,dan IF. Untuk mengetahui keberadaan multikolinieritas, maka dapat 
digunakan metode Klein's rule of thumb yang dilakukan dengan menghitung koefisien korelasi antar variabel bebas dengan tingkat signifikansi model regresi bebas dari masalah multikonieritas yakni $<0,8$. Dari hasil perhitungan dengan menggunakan software eviews 6.0 dalam pengujian multikonieritas, diperoleh hasil sebagai berikut:

Tabel 7: Nilai Korelasi Parsial

\begin{tabular}{lrrrrr}
\hline & I_LN & PDRB_LN & JP_LN & PP_LN & IF_LN \\
\hline I_LN & & 0.578234 & -0.247021 & 0.645345 & -0.036628 \\
\hline PDRB_LN & 0.578234 & & -0.087621 & 0.673616 & -0.122054 \\
\hline JP_LN & -0.247021 & -0.087621 & & 0.048703 & 0.025488 \\
\hline PP_LN & 0.645345 & 0.673616 & 0.048703 & & -0.210536 \\
\hline IF_LN & -0.036628 & -0.122054 & 0.025488 & -0.210536 & \\
\hline
\end{tabular}

Sumber: Data Penelitian Diolah

Berdasarkan tabel 7, nilai korelasi dari kelima variabel bebas yaitu logaritma I, PDRB, JP, PP, dan IF menunjukkan nilai kurang dari 0.8, sehingga dapat diambil kesimpulan bahwa model regresi tersebut bebas dari masalah multikolinieritas.

Uji heterokedastisitas bertujuan untuk mendeteksi terjadinya nilai varian yang berbeda dari setiap varian variabel bebas yaitu logaritma I, PDRB, JP, PP, dan IF di dalam model regresi. Untuk mendeteksi ada atau tidaknya masalah heterokedastisitas di dalam model regresi, penelitian ini menggunakan uji White. Dari hasil perhitungan dengan menggunakan software eviews 6.0 dalam pengujian multikonieritas, diperoleh hasil sebagai berikut:

Tabel 8: Pengujian Heterokedastisitas dengan Uji White

\begin{tabular}{|ll|}
$\mathrm{R}-$ Squared & $=0.962$ \\
Obs $* R$-Squared & $=26.953$ \\
Prob & $=0.079$ \\
$\mathrm{~N}$ & $=28$ \\
\hline
\end{tabular}

Sumber: Data Penelitian Diolah

Berdasarkan tabel 8, dapat diperoleh hasil Obs* $\mathrm{R}$-squared $(\mathrm{N}$ x R. Squared) $=28 \times 0.962=26.953$. dan nilai Sig (Prob) sebesar 0.079. karena nilai Prob > 0.05, maka dapat disimpulkan bahwa hasil regresi antara logaritma I, PDRB, JP, PP, dan IF terhadap PAD, tidak terdapat masalah heterokedastisitas. 
Uji autokorelasi digunakan untuk mengetahui ada atau tidaknya masalah aotokorelasi dimana unsur gangguan yang berhubungan dengan observasi dipengaruhi oleh unsur disturbansi atau gangguan yang berhubungan dengan observasi lain. Untuk mengetahui adanya autokorekasi dalam suatu model regresi dilakukan dengan pengujian terhadap nilai uji Durbin Watson (DW) dengan ketentuan sebagai berikut (dari tabel Durbin Watson diperoleh nilai dL sebesar $1.571 \mathrm{dan}$ dU sebesar 1.780, sehingga diperoleh 4-dU sebesar 2.220 dan 4-dL sebesar 2.429):

Tabel 9: Pegujian Autokorelasi Durbin Watson

\begin{tabular}{ll}
\hline \multicolumn{1}{c}{ Nilai Durbin Watson } & \multicolumn{1}{c}{ Kesimpulan } \\
\hline Kurang dari 1.571 & Ada autokorelasi \\
\hline 1.571 sampai dengan 1.780 & Tanpa Kesimpulan \\
\hline 1.780 sampai dengan 2.220 & Tidak ada autokorelasi \\
\hline 2.220 sampai dengn 2.429 & Tanpa Kesimpulan \\
\hline lebih dari 2.429 & Ada autokorelasi \\
\hline
\end{tabular}

Berdasarkan data tabel 9, diperoleh hasil regresi nilai DW-Stat sebesar 1.806 maka dapat di ambil kesimpulan bahwa nilai DW statistik terletak antara interval 1,780 sampai dengan 2,220. Sehingga dapat diambil kesimpulan bahwa model regresi antara I, PDRB, JP, PP, dan IF terhadap PAD, tidak terdapat masalah autokorelasi. Uji Normalitas merupakan uji untuk mengetahui normalitas (normal atau tidaknya) faktor pengganggu $\mathrm{e}_{\mathrm{t}}$ (error terms).
Sebagaimana telah diketahui bahwa faktor pengganggu tersebut diansumsikan memiliki distribusi normal sehingga uji t-Stat dan F-Stat dapat dilakukan. Untuk dapat menguji normalitas model regresi, penelitian ini menggunakan metode Jarque-Bera test $(J-B$ test $)$. Dari hasil perhitungan dengan menggunakan software eviews 6.0 diperoleh nilai Jarque-Bera statistik sebagai berikut:

Tabel 10: Pegujian Normalitas Jarque-Bera test (J-B test)

\begin{tabular}{lr}
\hline Skewness & -0.480 \\
\hline Kurtosis & 3.594 \\
\hline & \\
\hline Jarque-Bera & 1.489 \\
\hline Probability & 0.474 \\
\hline
\end{tabular}


Dari tabel 10, nilai JarqueBera statistik model regresi menujukkan nilai 1.489 dengan Probability sebesar 0.474. Karena nilai Prob lebih besar dari 0.05 (tingkat kesalahan 5\%), maka asumsi normalitas telah terpenuhi.Dari hasil pengujian asumsi, keempat asumsi yaitu multikolinieritas, autokorelasi, heteroskedastisitas dan normalitas telah terpenuhi. Sehingga analisis regresi yang digunakan untuk diiinterpretasikan adalah analisis regresi hasil transformasi logaritma.

Analisis regresi linier berganda dalam penelitian ini bertujuan untuk mengetahui apakah nilai Investasi, PDRB, Jumalh Penduduk, Penerimaan Pembangunan, dan Inflasi terhadap Tabel 11: Hasil Estimasi Model Regresi

\begin{tabular}{|c|c|c|c|}
\hline VARIABEL & $\begin{array}{l}\text { KOEFISIE } \\
\mathrm{N}\end{array}$ & t-STAT & PROB \\
\hline I & 0.110043 & 2.324451 & 0.0297 \\
\hline PDRB & 0.877801 & 11.68110 & 0.0000 \\
\hline JP & 0.135519 & 0.341649 & 0.7359 \\
\hline $\mathrm{PP}$ & 0.201545 & 5.341202 & 0.0000 \\
\hline IF & 0.101281 & 2.040741 & 0.0535 \\
\hline $\begin{array}{ll}\text { R-Squared } & =0.985 \\
\text { F-Stat } & =307.625 \\
\text { F-Prob } & =0.000\end{array}$ & & & \\
\hline
\end{tabular}

Sumber: Data Penelitian Diolah

Selanjutnya dari hasil estimasi tabel 11 tersebut dilakukan penilaian keaktualan dan keakuratan
Pendapatan Asli Daerah (PAD) dinyatakan dalam persamaan matematis yang memiliki hubungan secara fungsional dengan formulasi sebagai berikut PAD $=\beta_{0}+\beta_{1} I+$ $\beta_{2} \mathrm{PDRB}+\beta_{3} \mathrm{JP}+\beta_{4} \mathrm{PP}+\beta_{5} I F+\mathrm{e}_{\mathrm{t}}$.

Untuk dapat menjelaskan pengaruh antara variabel bebas terhadap variabel terikat, penelitian ini menggunakan metode OLS (Ordinary least square) yang diregresikan dengan menggunakan bantuan software eviews 6.0. Berdasarkan hasil analisis regresi dengan menggunakan metode OLS (Ordinary Least Square) diperoleh hasil sebagai berikut: 
untuk mengetahui apakah variabel bebas yakni I, PDRB, JP, PP, dan IF berpengaruh secara bersama-sama terhadap variabel terikat yakni Pendapatan Asli Daerah (PAD).

Berdasarkan Tabel di atas, nilai $\mathrm{F}$ statistik menunjukkan angka sebesar 307.625, maka dengan tingkat signifikansi $(\alpha)=5 \%$ dan nilai df (Degree of Freedom) pembilang sebesar 5 dan df penyebut sebesar $\mathrm{n}-1-5=100-1-5=94$ diperoleh F-tabel sebesar 2.661 . Diperoleh pula perhitungan Prob sebesar 0.000 .

Berdasarkan hasil analisis diatas, maka pengujian F statistik $>\mathrm{F}$ tabel (307.625 > 2.661). Demikian pula nilai Prob $<0.05$. Hal ini memberikan kesimpulan untuk menolak hipotesis $\mathrm{H}_{0}$ dan menerima $\mathrm{H}_{\mathrm{i}} \quad$ Sehingga menunjukkan hasil bahwa variabel bebas yaitu I, PDRB, JP, PP, dan IF secara bersama-sama memiliki pengaruh signifikan terhadap variabel terikat yaitu PAD.

Uji t-statistik merupakan pengujian untuk mengetahui apakah variabel bebas yakni I, PDRB, JP, PP, dan IF secara individu (parsial) mempunyai pengaruh yang signifikan terhadap variabel terikat yakni PAD. Dengan pengujian $t$ statistik dua arah, tingkat signifikansi $(\alpha)=5 \%$ dan nilai df (Degree of Freedom) sebesar 94, diperoleh ttabel sebesar 2.073, maka menghasilkan pengujian $\mathrm{t}$ statistik sebagai berikut Berdasarkan tabel di atas, maka interpretasi terhadap hasil perhitungan adalah sebagai berikut:

Pengujian Variabel I (Investasi) secara parsial terhadap PAD, diperoleh nilai t-statistik sebesar 2.324, dengan nilai probabilitas-t sebesar 0.029. Dari tabel statistik dengan alpha 5\%, diperoleh t-tabel sebesar 2.073. Karena nilai t-statistik > t-tabel (2.324> 2.073), dan nilai Probabilitas $<0.05(0.029<0.05)$, maka $\mathrm{H}_{0}$ dalam penelitian ditolak. Hal ini mengindikasikan terdapat pengaruh yang signifikan antara variabel I (Investasi) terhadap PAD. Mengingat koefisien bertanda positif (0.110) mengindikasikan hubungannya positif atau searah. Artinya semakin tinggi nilai I (Investasi), akan semakin tinggi pula Pendapatan Asli Daerah.

Pengujian Variabel PDRB (Produk Domestik Rate Bruto) secara parsial terhadap PAD, 
diperoleh nilai t-statistik sebesar 11.681, dengan nilai probabilitas-t sebesar 0.000. Dari tabel statistik dengan alpha $5 \%$, diperoleh t-tabel sebesar 2.073. Karena nilai t-statistik $>$ t-tabel $(11.681>2.073)$, dan nilai Probabilitas $<0.05(0.000<0.05)$, maka $\mathrm{H}_{0}$ dalam penelitian ditolak. Hal ini mengindikasikan terdapat pengaruh yang signifikan antara variabel PDRB (Produk Domestik Rate Bruto) terhadap PAD. Mengingat koefisien bertanda positif (0.110) mengindikasikan hubungannya positif atau searah. Artinya semakin tinggi nilai PDRB (Produk Domestik Rate Bruto), akan semakin tinggi pula Pendapatan Asli Daerah.

\section{Pengujian Variabel JP (Jumlah Penduduk) secara parsial terhadap PAD, diperoleh nilai $\mathrm{t}$ - statistik sebesar 0.341 , dengan nilai probabilitas-t sebesar 0.735. Dari tabel statistik dengan alpha 5\%, diperoleh t-tabel sebesar 2.073. Karena nilai $\mathrm{t}$-statistik $<\mathrm{t}$-tabel $(0.341<2.073)$, dan nilai Probabilitas > $0.05(0.735>0.05)$, maka $\mathrm{H}_{0}$ dalam penelitian diterima. Hal ini mengindikasikan tidak terdapat pengaruh yang signifikan}

antara variabel JP (Jumlah Penduduk) terhadap PAD. Artinya berapapun besarnya JP (Jumlah Penduduk), tidak akan berpengaruh terhadap tinggi rendahnya nilai Pendapatan Asli Daerah.

d. Pengujian Variabel PP (Penerimaan Pembangunan) secara parsial terhadap PAD, diperoleh nilai t-statistik sebesar 5.341, dengan nilai probabilitas-t sebesar 0.000. Dari tabel statistik dengan alpha 5\%, diperoleh t-tabel sebesar 2.073. Karena nilai t-statistik > t-tabel $(5.341>2.073)$, dan nilai Probabilitas $<0.05(0.000<0.05)$, maka $\mathrm{H}_{0}$ dalam penelitian ditolak. Hal ini mengindikasikan terdapat pengaruh yang signifikan antara variabel PP (Penerimaan Pembangunan) terhadap PAD. Mengingat koefisien bertanda positif (0.201) mengindikasikan hubungannya positif atau searah. Artinya semakin tinggi nilai PP (Penerimaan Pembangunan), akan semakin tinggi pula Pendapatan Asli Daerah.

Pengujian Variabel IF (Inflasi) secara parsial terhadap PAD, diperoleh nilai t-statistik sebesar 2.040, dengan nilai 
probabilitas-t sebesar 0.053. Dari tabel statistik dengan alpha 5\%, diperoleh t-tabel sebesar 2.073. Karena nilai $\mathrm{t}$-statistik $<\mathrm{t}$-tabel $(2.040<2.073)$, dan nilai Probabilitas > $0.05(0.053>0.05)$, maka $\mathrm{H}_{0}$ dalam penelitian diterima. Hal ini mengindikasikan tidak terdapat pengaruh yang signifikan antara variabel IF (Inflasi) terhadap PAD. Artinya berapapun besarnya IF (Inflasi), tidak akan berpengaruh terhadap tinggi rendahnya nilai Pendapatan Asli Daerah.

Uji $\mathrm{R}^{2}$ digunakan untuk mengukur seberapa besar variasi ( jumlah kuadrat simpangan suatu variabel dari nilai rata-ratanya) dari variabel terikat dapat dijelaskan oleh variabel bebasnya dalam model regresi, sehingga dapat mengetahui kecocokan model regresi tersebut (goodness of fit).

Berdasarkan

Tabel

sebelumnya, menunjukkan hasil estimasi diperoleh nilai $\mathrm{R}$ Square sebesar 0.985 yang berarti sebesar 98.5\% variasi perubahan PAD dapat dijelaskan/dipengaruhi oleh adanya Inflasi, Produk Domestik Rate Bruto, Jumlah Penduduk, Penerimaan Pembangunan, dan Inflasi, sedangkan sisanya sebesar $1.5 \%$ dipengaruhi oleh variabel lain di luar model regresi.

Faktor-faktor eksogen yang diduga mempengaruhi presentase perubahan PAD adalah Investasi, PDRB, Jumlah Penduduk, Penerimaan Pembangunan, dan Inflasi, hal ini dapat dilihat dari hasil regresi bahwa kelima variabel bebas tersebut bebas dari masalah multikolinieritas, heterokedastisitas dan autokorelasi, namun nilai jarqueBera statistik model regresi menunjukkan nilai probalitas masih kecil, maka asumsi normalitas belum terpenuhi sehingga perlu melakukan tindakan perbaikan dengan melakukan transpormasi logaritma. Dari ke lima variabel bebas tersebut yang mempunyai pengaruh yang signifikan terhadap PAD adalah variabel invertasi, variabel PDRB dan variabel Penerimaan Pembangunan sedangkan variabel jumlah penduduk, dan variabel inflasi tidak mempunyai pengaruh yang signifikan terhadap PAD, yang artinya berapapun besarnya jumlah penduduk tidak akan berpengaruh terhadap tinggi rendahnya nilai PAD begitu juga dengan inflasi. 
Berapapun besarnya inflasi, tidak akan berpengaruh terhadap tinggi rendahnya nilai PAD. Berdasarkan kesimpulan tersebut diatas maka yang menjadi saran pada penulisan ini adalah dieperlukan adanya suatu kebijakan pemerintah (interpensi pemerintah) yang tepat, sehingga jumlah penduduk dan inflasi dapat berpengaruh secara signifikan terhadap PAD.

\section{DAFTAR PUSTAKA}

Anonim. 2005. Pelaksanaan Keuangan Daerah dan Program

Penstrada.Htt://www.surabay a.go.M/pdf/Aku/Bab2.pdf.

Djojosubroto, Dono Iskandar. 1992. Masalah dan Prospek Pembiayaan Pembangunan Daerah, Makalah pada Munas ISEI VII, 8 September 1992, Banjarmasin.

Gujarati, Damodar 2002. Ekonometrika Dasar. Jakarta : Erlangga.

Halim,Abdul. 2001. Manajemen Keuangan Daerah. Penerbit UPP AMP YKPN Yogyakarta.

Ichsan, Moch, Ratih Nur Pratiwi, Trilaksono Nugroho. 1997. Administrasi Keuangan Daerah : Pengelolaan dan Penyusunan Anggaran Pendapatan dan Belanja Daerah (APBD), Cetakan Pertama. PT. Danar Wijaya,
Brawijaya Universitas Press. Malang.

Iswandono, 1999. Uang dan Bank $B P F E$, Yogyakarta.

Kaho, Joseph Riwu. 1997. Prospek Otonomi Daerah di Negara Republik Indonesia. PT. Grafindo Persada. Jakarta.

Kristiadi J.B. 1998. Masalah Sekitar Pendapatan Daerah. Prisma No. 12 LP3ES. Jakarta, Hal. 40-57.

Koswara, E. 2000. "Menyonsong Pelaksanaan Otonomi Daerah Berdasarkan Undang-Undang Nomor 22 Tahun 1999: Suatu Telaahan dan Menyangkut Kebijakan, Pelaksanaannya dan Kompleksitasnya". CSIS XXIX Nomor 1. Jakarta.

Mamesah,D.J. $1997 . \quad$ Sistem Administrasi Keuangan Daerah, PT. Gramedia Pustaka Utama, Jakarta.

Mankiw N, 2002, Teori Makro Ekonomi, Edisi keempat, Penerbit Erlangga, Jakarta.

Mardiasmo, 2004. Otonomi dan Manajemen Keuangan daerah, Penerbit Andi Offset, Yogyakarta.

Raharja, Pratama, dan Mandala, Manurung, 2004, "Teori Ekonomi Makro", Lembaga Penerbit Fakultas Ekonomi Indonesia, Jakarta.

Rosidi, Suherman, 2002, Pengantar Teori Ekonomi, Pendekatan Kepada teori Ekonomi Mikro 
dan Makro, Edisi Baru, Penerbit PT. Raja Grafindo Persada, Jakarta.

Sumitro, R. 1997. Dasar-Dasar Hukum Pajak dan Pajak Pendapatan. Erasco, Jakarta.
Todaro, Stephen C. Smith, 2006. Pembangunan Ekonomi, Edisi kesembilan, Penerbit Erlangga, Jakarta. 